\title{
Pentingnya Pendidikan Demokrasi Pada Remaja
}

Indah Aprilia Angelina

IIK Strada Indonesia

indahaprang25@gmail.com

Absrak

Pendidikan yang demokratik adalah pendidikan yang memberikan kesempatan yang sama kepada setiap anak untuk mendapatkan pendidikan di sekolah sesuai dengan kemampuannya. Pengertian demokratik di sini mencakup arti baik secara horizontal maupun vertikal.

Kata kunci : pentingnya pendidikan demokrasi pada remaja

Abstrac

Democratic education is education that provides equal opportunities for every child to get an education in schools according to their abilities. The definition of democracy here includes the meaning both horizontally and vertically.

Keywords : the importance of democratic education for youth

A. Latar belakang

Pendidikan yang demokratik adalah pendidikan yang memberikan kesempatan yang sama kepada setiap anak untuk mendapatkan pendidikan di sekolah sesuai dengan kemampuannya. Pengertian demokratik di sini mencakup arti baik secara horizontal maupun vertikal.

Maksud demokrasi secara horizontal adalah bahwa setiap anak, tidak ada kecualinya, mendapatkan kesempatan yang sama untuk menikmati pendidikan sekolah. Hal ini tercermin pada UUD 1945 pasal 31 ayat 1 yaitu : "Tiap-tiap warga negara berhak mendapat pengajaran". Sementara itu, demokrasi secara vertikal ialah bahwa setiap anak mendapat kesempatan yang sama untuk mencapai tingkat pendidikan sekolah yang setinggi-tingginya sesuai dengan kemampuannya.

Menurut Kamus Besar Bahasa Indonesia, demokrasi diartikan sebagai gagasan atau pandangan hidup yang mengutamakan persamaan hak dan kewajiban serta perlakuan yang sama bagi semua warga negara. Dalam pendidikan, demokrasi ditunjukkan dengan pemusatan perhatian serta usaha pada si anak didik dalam keadaan sewajarnya (intelegensi, kesehatan, keadaan sosial, dan sebagainya). Di kalangan Taman Siswa dianut sikap

C. Pembahasan

Indonesia adalah negara yang sangat luas dengan beribu pulau yang terpisah oleh lautan yang tutwuri handayani, suatu sikap demokratis yang mengakui hak si anak untuk tumbuh dan berkembang menurut kodratnya.

Dengan demikian, tampaknya demokrasi pendidikan merupakan pandangan hidup yang mengutarakan persamaan hak dan kewajiban serta perlakuan yang sama di dalam berlangsungnya proses pendidikan antara pendidik dan anak didik, serta juga dengan pengelola pendidikan.

B. Tinjauan pustaka

Kata "demokrasi" berasal dari dua kata, yaitu demos yang berarti rakyat, dan kratos/cratein yang berarti pemerintahan. Demokrasi sendiri menurut Hans Kelsen berarti bahwa "kehendak" yang dinyatakan dalam tatanan hukum negara identik dengan kehendak dari para subyek hukum.

Demokrasi langsung adalah demokrasi dengan derajat relatif paling tinggi dan ditandai oleh fakta bahwa pembuatan undang-undang dan juga fungsi eksekutif dan yudikatif yang utama dilaksanakan oleh rakyat di dalam pertemuan akbar atau rapat umum utnuk mekanisme sistem pemerintahan negara sebagia upaya mewujudkan kedaulatan rakyat (kekuasaan warganegara) atas negara yang dijalankan pemerintah negara tersebut

tidak kalah luasnya juga. Dari situlah dengan negara beribu pulau ini memerlukan suatu sistem untuk tetap bersatu meski tempat pulau terpisah antara pulau yang satu dengan yang lainya. Seperti symbol yang 
tertera pada lambang negara yakni burung garuda

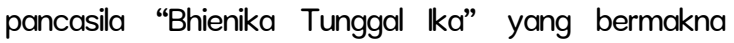
berbeda-beda tetapi tetap satu jua, satu jua yakni atas nama Indonesia. Indonesia sebagai negara, negara wadah bangsa untuk mencapai cita-cita atau tujuan bangsanya. Negara Indonesia dalam usaha mewujudkan cita cita itu salah satunya adalah menggunakan resep demokrasi. Perkembangan demokrasi dari demokrasi kuno hingga demokrasi modern ini terjadi sekitar abad ke XVII dan abad ke $X V I I I$, yang dalam hal ini nantinya erat hubunganya dengan ajaran-ajaran para sarjana hukum alam.

Secara etimologis demokrasi berasal dari bahasa Yunani yaitu "demokratia" yang terdiri dari dua kata yaitu "demos" yang artinya rakyat dan "kratos/kratein" yang artinya kekuatan atau pemerintahan. Secara harfiah demokrasi berarti kekuatan rakyat atau suatu bentuk pemerintahan negara dengan rakyat sebagai pemegang kedaulatannya. Melaui konteks budaya demokrasi, nilai-nilai, dan norma-norma yang menjadi panutan dapat diterapkan dalam praktik kehidupan demokratis yang tidak hanya dalam pengertian politik saja tetapi juga dalam berbagai bidang kehidupan. Mohammad Hatta sebagai wakil presiden pertama di Indonesia, menyebut demokrasi sebagai sebuah pergantian atau pergeseran kedaulatan raja menjadi kedaulatan rakyat

Menganalisis struktur anarkisme generasi muda (anomali kebebasan hak menyatakan pendapat)

\section{Demokrasi}

Saat ini Demokrasi Indonesia dinilai masih berada dalam tahap transisi, yaitu tahap di mana hak dan kewajiban belum mampu bersinergis. Padahal, bayangbayang kewajiban selalu melekat kuat mengikuti hak, begitu pula sebaliknya. Sebagian masyarakat hanya tahu bahwa mereka bebas bicara, beraspirasi, dan berdemo, tanpa tahu semua itu mengandung konsekuensi natural yaitu tanggung jawab. Keadaan yang demikian kacau pada akhirnya menjatuhkan generasi muda ke dalam kubangan anomali kebebasan pemerintah, yang celakanya banyak dilakukan secara Contoh perilaku demokrasi :

1) Tidak membeda-bedakan teman

2) Menghargai pendapat teman maupun kelompok sekitar

3) Tidak memaksakan kehendak hak berpendapat. Sungguh realita yang sangat ironis, jikamengingat (hope) idealnya sistem demokrasi di suatu negara.

2. Moral-etika

Problem utama yang ditawarkan dalam kerangka dasar persoalan anarkisme di kalangan generasi muda adalah dekadensi moral-etika. Pembangunan nasional yang berkembang pesat di beberapa bidang , ternyata tidak diimbangi oleh restorasi moral -etika generasi muda. Sebagai contoh mudah, aksi demonstrasi mahasiswa yang sering melampaui batas-batas kewajaran. Mulai dari merusak fasilitas umum, hingga merobek serta membakar lambang-lambang negara yang seharusnya dihormati. Chaos yang ada bertambah parah ketika menyoroti lunturnya nilai solidaritas sosial, musyawarah -mufakat, kekeluargaan, sopan santun, kejujuran, rasa malu dan cinta tanah air. Perilaku-perilaku moral-etika kini juga tidak lagi disandarkan pada faham utilitarianisme (The Greates Happiness Theory) komunal, melainkan primordial.

3. Pemerintah atas suara masyarakat luas

Tugas pemerintah yang tidak kalah penting selain mengeksekusi program adalah listen and take action terhadap aspirasi masyarakat. Perlu ditekankan, menerima aspirasi bukan lantas menjadi indikator akan vonis pemerintahan yang aspiratif. Pemerintah disebut aspiratif jika memiliki progress tidak hanya menerima aspirasi semata, tetapi juga mau mengelola dan menindaklanjutinya dengan baik. Berikutnya muncul pertanyaan, apakah pemerintah sudah seperti itu? Aspirasi yang bisa dianggap sebagai suplemen motivasi untuk pemerintah ternyata kurang diperhatikan, sehingga berdampak pada ketidakpuasan masyarakat, termasuk generasi muda. Hal tersebut kemudian menjadi pemantik timbulnya pressure kepada

tidak terkontrol.

4) Memiliki rasa malu

5) Menyelesaikan masalah dengan bermusyawarah

D. Kesimpulan

Demokrasi merupakan sistem yang paling 
tepat untuk dipakai suatu negara dalam era modern ini. Tidak ada alasan lain untuk tidak menggunakan/menolak sistem demokrasi. Mengenai realita yang ada sekarang terkait anomali kebebasan hak menyatakan pendapat, itu bukan kesalahan demokrasi, tetapi kesalahan pelaku (subjek) demokrasi itu sendiri (tataran behavioral).

Generasi muda perlu memahami lebih jauh konsekuensi alamiah dari kebebasan (hak),

yaitu tanggung jawab (kewajiban). Anarkisme, dalam konteks apapun tidak dapat dibenarkan, meski mengatasnamakan prinsip kebebasan dan demokrasi. Mengemukakan pendapat dengan

mekanisme-mekanisme positif, akan menempatkan generasi muda diposisi layak, sebagai The

Real Agent of Change and Control. Setiap tindakantindakan yang diambil, hendaknya juga mengandung moral force (daya moral) agar dihargai orang lain. Di sini, urgennya kecerdasan dalam berdemokrasi dan pendidikan karakter 
Edukasi, Sisi (2016). MAKALAH PENTINGNYA PENDIDIKAN DEMOKRASI UNTUK GENERASI MUDA. https://contohmakalahdocx. blogspot. com/2016/04/contoh-makalah-demokrasi-pentingnya. html

$\begin{array}{llllll}\text { UMY, } & \text { Repository } & \text { (2017). } & \text { BAB } & \text { TINJAUAN } & \text { PUSTAKA. }\end{array}$ http://repository. umy. ac. id/bitstream/handle/123456789/16892/F. \%2OBAB\%2Oll. pdf? sequence=6\&isAllowed=y

UMM, Eprin (2014). BAB II TINJAUAN PUSTAKA. http://eprints. umm. ac. id/44095/3/BAB\%2OI. pdf

Angelina, I. A. (2021, November 10). Menerapkan Nilai Persatuan Dan Kesatuan Dalam Sehari-Hari. https://doi. org/10. 31219/osf. io/gj8te

Angelina, I. A. (2021, November 10). Penghimbauan Protokol Kesehatan Saat Pandemi. https://doi. org/10. 31219/osf. io/wjb4y

Sodik, M. A. (2014). Sikap Pencegahan Aborsi Ditinjau Dari Pengetahuan Tentang Bahaya Dan Resiko Kesehatan. Strada Jurnal Kesehatan http://publikasi. stikesstrada. ac. id/wpcontent/uploads/2015/02/9-SIKAP SIKAPPENCEGAHAN-ABORSI. pdf.

Sodik, M. A. (2015). The "Kimcil" Phenomenon: Sexual Know ledge and Safe Sex Behaviour among Adoles centsin Kediri. In The $1^{\text {st }}$ Joint International Conference.

Siyoto, S., Dwianggimawati, M. S., Sari, D. K., Mufida, R. T., \& Sodik, M. A. (2018). The Effect of Pornography Accessity to Influence Sexual Behavior. Indian Journal of Public Health Research \& Development, 9(12).

Sodik, M. A., Astikasari, N. D., Fazrin, I., Chusnatayaini, A., \& Peristiowati, Y. (2018). Dental health child with retardation mental and parents behavior. Indian Journal of Physiotherapy and Occupational Therapy-An International Journal, 12(4), 278-282.

Sodik, M. A. (2018, September). Analysis of Improved Attitude of Youth in HIV/AIDS Prevention through the Provision of Health Education with Peer Education. In The 2nd Joint International Conferences (Vol. 2, No. 2, pp. 495-502).

Sodik, M. A., \& Nzilibili, S. M. M. (2017). The Role Of Health Promotion And Family Support With Attitude Of Couples Childbearing Age In Following Family Planning Program In Health. Journal of Global Research in Public Health, 2(2), 82-89. 
Attoriq, S., \& Sodik, M. A. (2018). Pencegahan Dan Pengendalian Infeksi Terkait Pelayanan Kesehatan Di Lahan Praktik.

Sari, N., Yudhana, A., Wahyuni, C., Rusmawati, A., \& Sodik, M. A. (2018). Family support as a determinant safety riding student behavior in SMKN 2 Kediri. Indian Journal of Physiotherapy and Occupational Therapy-An International Journal, 12(4), 230-234.

Sodik, M. A., \& Setyani, A. T. (2018). Effect of Smoking For Teens Against Behavior and Social Interaction. 